\title{
MIMR EMMERGENCE OF ZIKA VIRUS: AN INTERPLAY OF VIRUS, VECTOR AND VERTEBRATE HOSTS
}

\author{
Sajal Bhattacharya ${ }^{1 *}$, Shakya Sinha², Debasmita Baidya', Sandeep Poddar ${ }^{3}$, Indranil Sikder ${ }^{1}$ \\ ${ }^{1}$ Department of Zoology, Asutosh College (University of Calcutta), India \\ ${ }^{2}$ Department of Zoology, Dinabandhu Andrews College (University of Calcutta), India \\ ${ }^{3}$ Senior Research Director, Lincoln University College, Malaysia \\ *Corresponding Author's Email:sajal_58@rediffmail.com
}

\begin{abstract}
Zika virus (ZIKV) is a mosquito-borne zoonotic flavivirus. The epidemiology of this emergent hitherto neglected disease has become a poignant interest in the context of the recent outbreaks in South America. The severe impact of which led World Health Organization (WHO) to declare a Public Health Emergency (PHE) of International concern. Interestingly, two recognized and potential vectors of this virus, Aedes aegypti and Aedes albopictus, have been prevalent in most of the habitable continents in the world including the Indian sub-continent. In accordance to the earlier apprehension, several cases of ZIKV were reported in 2017 and 2018 from the states of Gujarat and Rajasthan in Western India. Studies indicated that the emerging arboviral infections generally stemmed from an animal reservoir, but there is inadequate information on the natural history of several arboviruses, like ZIKV, specially their methods of survival during the inter-epidemic period. Hence, a sustained vector-virus and vertebrate-host surveillance is an imperative necessity in Zika endemic and non-endemic regions to formulate strategies for the prevention offuture outbreak, if any. This review is an attempt to provide an understanding of the interplay of Zika virus and its vector/s and vertebrate host/s in reference to today's changing environment.
\end{abstract}

Keywords: Zika Virus, Vectors, Reservoir Hosts, Global Warming, Deforestation, Travels and Trades

\section{INTRODUCTION}

Zika virus, the mosquito-transmitted virus of family 'Flaviviridae', genus 'Flavivirus'. ZIKV was first identified and isolated from a sentinel rhesus monkey in April 1947 in the Zika forest, Uganda.The second isolation was in 1948 at the same site from Aedes africanus mosquito (Dick et al., 1952; Haddow et al., 2012). ZIKV has likely been endemic in certain regions of the world for a long time. However, only 14 cases of ZIKV infection was reported in humans before 2007(Posen et al., 2016). After 2007, ZIKV outbreak has affected three major continents namely Asia, Africa and America. Although most of the cases of ZIKV infection are devoid of any clinical manifestation, the major symptoms in this context are encephalitis along with other symptoms like fever, headache etc. Unfortunately, the symptoms of ZIKV infection are often misinterpreted with that of the dengue infection. In recent times, World Health Organization (WHO) has declared the outbreak of ZIKV infection as a Public health Emergency (PHE) of international concern, as the increasing reports of congenital abnormalities, such as microcephaly, have been spatiotemporally associated with ZIKV infection. It all started in the continent of Africa where ZIKV was first isolated. Later on a bidirectional territory-expansion took place from Africa. Expansion proceeded up to Nigeria and Senegal in the west while in the east it gradually invaded Eastern Africa as well as Asia. After the first detection of ZIKV in Uganda, serological and entomological data indicated the incidence of ZIKV infection throughout the African continent starting from 1951to 1999 in Nigeria, Central African Republic, Senegal, Cote d'Ivoire, Gabon, Sierra Leone (Fagbami, 1978; Georges et al., 1980; Le Gonidec, 1973, Chippaux et al., 1981; Bres 1970; Robin 1975) etc. Recently, ZIKV was detected in Senegal in 2011 and 2012. Emerging arboviral infections generally stemmed from an animal reservoir, but there is inadequate information on the natural history of the arboviruses, specially their methods of survival during the inter-epidemic period. This review is an attempt to provide an understanding of the interplay of Zika virus and its vector/s and vertebrate 
host/s in reference to today's changing environment.

\section{Lineages of Zika Virus}

Some scientists indicated that ZIKV emerged in Uganda around 1920, most probably between 1892 and 1942 (Faye et al., 2014). In 1961, the researchers isolated 12 strains of ZIKV from the zika forest (Imperato 2016). Genetic analysis and Cross neutralization tests confirmed that the virus is neither related to Yellow fever nor Hawaiian Dengue although they shared genomic and vectorial resemblance and even required the same ecological conditions to spread (Huber et al., 2019; Dick et al., 1952).

Initially ZIKV was classified into two major lineages namely African and Asian (Wang et al., 2016) but recent researches have provided the proof for existence of another lineage called the African II (Shen et al., 2016). After phylogenetic analysis of all viral sequences, African II can now be considered as the sister lineage of the two previously discovered lineages, and the initially identified African lineage is now named as African I. The genetic data collected from isolations all over the world confirms that the virus originated in East Africa and then spread to West Africa and Asia (Kuno et al., 2007). The African lineages of ZIKV are classified into two clusters namely MR766 cluster and Nigeria cluster. Recent isolations and identification of strains from African lineage were in Senegal, Cote d' Ivorie, Uganda, Central Republican of Africa, Nigeria and Gabon (Gong et al., 2016). The Asian lineage of ZIKV can be classified into different strains and those strains can be differentiated into various genotypes. In Asia, the first isolation of ZIKV was from Malaysia (Marchette et al., 1969) and then from Cambodia, Micronesia (Heang et al., 2010; Lanciotti et al., 2008) and French Polynesia. ZIKV infection might be circulating in Southeast Asia for over half a century and the recent evidences exhibits that a high level of genetic diversity of ZIKV in this region. The Asian ZIKV lineage has been found to be the reason behind the outbreaks in the Americas (Liu et al., 2019). The recent studies confirm that African strains have shown a higher transmission rate and infection prevalence than that of the Asian strains in Aedes aegypti (Simonin et al., 2017). It has been reported that Asian-lineage strains replicate at low levels in the tissues, months after the initial infection, whereas in case of African strains the number of such conditions is also significant (Simonin et al., 2017).

\section{Evolution of Zikv: Phenotypical and Molecular Aspects}

ZIKV also has high mutational rate and ecological adaptability. Initially it was confined within the forest ecosystem and the host range was also narrower. Mainly, the non-human primates of the forest were the reservoir and amplifier hosts of ZIKV. There are probably three main interlinked reasons behind the evolution of ZIKV in the $21^{\text {st }}$ century, i.e., urbanization, travel and viral evolution. Urbanization and establishment of megacities in tropical environments are favorable for $A$. aegypti to expand its home range (Li et al., 2014). Deforestation comes hand in hand with urbanization resulting in the reduction of the forest ecosystem, leading to habitat destruction of large varieties of animals. Hence, a potential rewiring of host-parasite and prey-predator interactome (a whole set of molecular interactions) is required. Changes in the abundance of various components of the ecosystem or a community pathogen's including viruses have faced a constant pressure for modifying its host range (Alera et al., 2012). Global warming and expansion of territory of the vectors are indirectly related to each other as the rise of temperature is allowing $A$. aegypti to overcome geographical restrictions that are caused by low temperature (Paixao et al., 2018). A. albopictus, another potential vector of several arboviruses including ZIKV, is now found in different parts of the world and can be referred to as global vector (Bhattacharya, 2009). Under the influence of all these factors ZIKV has evolved through constant genetic changes in a multi-lineage fashion.

International and domestic travel also helped ZIKV to overcome geographical barriers. Infected humans can act as introducer of ZIKV during their travel to non endemic areas. During the period of November 2015 to September 2017, total number of travel-associated Zika cases was reported to be 588 in California, which included 139 infected pregnant women. Among them, 10 congenital infections were reported and sexually transmitted infections were 8 in numbers (Porse et al., 2018).

The genetic recombination events along the entire genome of ZIKV have been found to be significant. Recent studies indicated that ZIKV may have experienced several recombination events, which is uncommon among flaviviruses (Simon-Loriere \& 
Holmes, 2011). There are 13 different sites of genetic recombination that have been reported throughout the entire genome of ZIKV. Some sites, encounter positive selection pressure for recombination, while some other sites have experienced negative selection pressure. However, these two different selection pressures account for the adaptability and survivability of the ZIKV. Sequential blood-meals taken from different hosts help to bring multiple strains together and thus facilitate the events of recombination (Faye et al., 2014). ZIKV has maximum sequence similarities in genome with DENV2 (54.5\%) (Mourya et al., 2016) among other flaviviruses and have common vectors, reservoir hosts with DENV and Yellow Fever Virus. The recombination events in Flavivirus can be both intergenomic and intragenomic (Taucher et al., 2010). It has been evident that the occurrence of ZIKV is more frequent, with an interval of 1-2 years in comparison to the cycle of DENV and yellow fever virus which occurs at an interval of 5-8 years. Such frequent activity can help in co-circulation and recombination of multiple genotypes of the ZIKV in forest environment (Faye et al., 2014). Dengue antibody dependent immune enhancement might also contribute to the dissemination of ZIKV and severe disease outcome (Liu et al., 2019).

\section{Aedes-Zika Co-Evolution}

The co-evolution of ZIKV with Aedes mosquito adds further to the complexity of the situation. It has been found that ZIKV is not solely dependent on A. aegypti or A. albopictus for its transmission, rather it is expanding its range of vectors via change in N-linked glycosylation sites of the envelop protein(E) (Sirohi et al., 2016). For virus-vector interaction these glycosylation sites have been proved to be important. Asn-154 residue in the alpha helix region of the envelop protein has been found to be a site for N-linkedglycosylation. A probable motif conserved for many ZIKV strain is 'Asn-x-Thr' (Faye et al., 2014). Throughout the history of ZIKV evolution, the Threonine residue of Asn-x-Thr has been mutated to Isoleucine for several times and has affected the subsequent interaction of Zika virus with the vector causing periodic outbreak of the disease. Aedes dalzieli, a zoophilic vector of ZIKV was possibly favored for adaptation by the loss of the Asn-154 glycosylation site in the envelope protein of ZIKV (Faye et al., 2014). This kind of adaptive co-evolution in Aedes and ZIKV can bring disastrous results in future via the accession of a broader range of hosts and reservoirs.

\section{Principal and Suspected Vectors of Zikv}

The principal vector for ZIKV in Africa is A. africanus. In Asia and America, A. aegypti and A. albopictus have been established as potential vectors. The different vectors of ZIKV and the places from which they have been detected have been listed in Table 1 .

Table 1: Mosquitoes from which Zika-virus (ZIKV) have been detected

\begin{tabular}{|c|c|c|c|}
\hline Year of collection & Mosquitoes involved & Location & Reference \\
\hline 1948 & Aedes africanus & $\begin{array}{l}\text { Zika Forest, } \\
\text { Uganda }\end{array}$ & $\begin{array}{l}\text { Dick et al., 1952; } \\
\text { G.W. Dick., } 1952\end{array}$ \\
\hline 1958 & Aedes africanus & $\begin{array}{l}\text { Zika Forest, } \\
\text { Uganda }\end{array}$ & $\begin{array}{c}\text { Weinbren \& } \\
\text { Williams, } 1958\end{array}$ \\
\hline 1964 & Aedes africanus & $\begin{array}{l}\text { Zika Forest, } \\
\text { Uganda }\end{array}$ & Haddow et al., 1964 \\
\hline 1969 & Aedes africanus, Aedes apicorgenteus & $\begin{array}{c}\text { Zika Forest, } \\
\text { Uganda, } \\
\text { Bwamba country }\end{array}$ & $\begin{array}{c}\text { Mccrae \& Kirya, } \\
1982\end{array}$ \\
\hline
\end{tabular}




\begin{tabular}{|c|c|c|c|}
\hline $1976-1980$ & Aedes africanus, Aedes opok & $\begin{array}{c}\text { Central African } \\
\text { Republic }\end{array}$ & Berthet et al., 2014 \\
\hline $1968-2002$ & $\begin{array}{c}\text { Aedes dalzielli, Aedes africanus, Aedes } \\
\text { aegypti, Aedes desfurcifer, Ae des } \\
\text { desgrahamii, Aedes luteocephalus, } \\
\text { Aedes vittatus, Aedes opock }\end{array}$ & $\begin{array}{l}\text { West Africa, } \\
\text { Central Africa } \\
\text { Republic }\end{array}$ & Faye et al.,2014 \\
\hline $1962-2008$ & $\begin{array}{c}\text { Aedes aegypti, Aedes dalzieli, Aedes } \\
\text { desfowleri, Aedes desfurcifer, Ae des } \\
\text { desluteocephalus, Aedes vittatus, Aedes } \\
\text { desneoafricanus, Aedes desmetallicus, } \\
\text { Aedes minutes, Anopheles africanus, } \\
\text { Anopheles coustani, Anopheles } \\
\text { gambiaes.I., Mansonia uniformis }\end{array}$ & Senegal & Althouse et al.,2015 \\
\hline 1969 & Aedes aegypti & Malaysia & $\begin{array}{c}\text { Marchette } \text { et al., } \\
1969\end{array}$ \\
\hline 2011 & $\begin{array}{l}\text { Aedes africanus, Aedes hirsutus, Aedes } \\
\text { metallicus, Aedes unilineatus, Culex } \\
\text { perfuscus, Aedes furcifer, Aedes vittatus, } \\
\text { Aedes taylori, Aedes luteocephalus, } \\
\text { Aedes dalzieli, Aedes aegypti, Mansonia } \\
\text { uniformis, Anopheles coustani }\end{array}$ & $\begin{array}{c}\text { South-eastern } \\
\text { Senegal }\end{array}$ & Diallo et al., 2011 \\
\hline 2011 & Aedes albopictus & Gabon & Grard et al., 2014 \\
\hline 2012 & Aedes aegypti & Singapore & Wong et al., 2013 \\
\hline 2014 & $\begin{array}{c}\text { Aedes henselli and Culex } \\
\text { quinquefasciatus showed negative } \\
\text { results for ZIKV; } \\
\text { Laboratory infection detected in Aedes } \\
\text { henselli }\end{array}$ & $\begin{array}{l}\text { Yap Island, } \\
\text { Federated States } \\
\text { of Micronesia }\end{array}$ & $\begin{array}{l}\text { Ledermann et al., } \\
2014\end{array}$ \\
\hline 2017 & Aedes aegypti, Aedes albopictus & India & WHO (2017) \\
\hline
\end{tabular}

The ZIKV was formerly isolated in Africa from Aedes africanus mosquitoes that were collected from Zika forest, Bwamba country, Uganda, in 1948, 1958 and 1964 (Dick et al.,1952; Weinbren \& Williams,1958; Haddow et al.,1964). In 1969, ZIKV was obtained from Aedes africanus and Aedes apicoergenteus collected from the Zika Forest, Uganda (Mccrae \& Kriya,1982).
However, a contemplative study was practiced in 2014 that investigated Aedes africanus and Aedes opok collected from the Central African Republic, West Africa, way back in 1976. This research included the phylogenetic analysis of the ZIKV strains that clustered together in their African lineages (Berthet et al., 2014). ZIKV has been proved to undergo many recombination 
events as detected in Aedes dalzieli, Aedes africanus, Aedes aegypti and Aedes furcifer. This was brought to light when the virus isolated from West Africa was examined in 1968 to 2002. This phenomenon could crucially be associated to the zoophilic mosquito Aedes dalzieli which harbors various ZIKV strains at the same time while taking blood meals from different animal species (Faye et al., 2014).Another contemplative study was carried out in Senegal, West Africa that examined the samples collected from 1962 to 2008. This showed that the ZIKV was present in Aedes aegypti, Aedes dalzieli, Aedes furcifer, Anopheles africanus, Anopheles coustani, Anopheles gambiae s.1. and Mansonia uniformis (Althouse et al., 2015).

ZIKV was isolated from Mansonia uniformis, Culex perfuscus and Anopheles coustani in 2011 from Southeastern Senegal (Diallo et al., 2014). In 2007, the very first infection of human with ZIKV was marked in Gabon, Central Africa. The emergence of Aedes albopictus, a specific mosquito species that invaded the urban areas of the country was probably the cause behind this (Grard et al., 2014). Till this time, ZIKV had not been distinctly recognized due to its similarities with dengue and chikungunya viruses (Grard et al., 2014). Central Africa and Mozambique in Southeast Africa has been invaded by Aedes albopictus that has replaced the native Aedes aegypti (Ngoagouni et al., 2015) and exhibits a vigorous augmentation of temperate climates all over the globe (Kampango \& Abilio, 2016).

The Aedes mosquitoes are prevalent in the Pacific, the most abundant being Aedes aegypti succeeded by Aedes albopictus (Ngoagouni et al., 2015) which are recognized for spreading chikungunya virus, dengue virus and ZIKV (Kampango \& Abilio, 2016). In the Asian lineage of ZIKV, they are considered to be the efficient vectors and their frequency has increased in 2011 to 2014 (Kampango \& Abilio, 2016). In 1969, ZIKV was isolated from Aedes aegypti (Calvez et al., 2016). An epidemiology of ZIKV among the human race was most probably propagated by Aedes aegypti in Indonesia in 1978 during monsoon but no research has been carried out to confirm the existence of ZIKV in the mosquito (Roth et al., 2014). However, an experiment that included inoculation of local Aedes aegypti with
Uganda strain of the ZIKV, showed the transmission of the virus in Singapore (Wong et al., 2013).

The most persistent mosquito among the twelve species belonging to four genera was Aedes henselli on Yap Island, in the Federated State of Micronesia. ZIKV was seen to be absent in the specimens that were collected in two studies (Olson \& Ksiazek, 1981; Ledermann et al., 2014). The experimental inoculation of ZIKV into Aedes henselli was carried out on Yap Island of with $80 \%$ being colonized among which $23 \%$ showed infection. Hence, it was uncertain whether Aedes henselli was a vector or not (Ledermann et al., 2014). On the other hand, in French Polynesia, the extensive epidemic that took place in October 2013, showed the presence of Aedes henselli more than any other species, concluding it to be a probable vector of ZIKV (Duffy et al., 2009) and at the epidemiological peak, Aedes aegypti and Aedes polynesiensis were pointed at.

In Brazil, the transmission has been carried out by Aedes aegypti and Aedes albopictus, Aedes aegypti was found both in the rural and urban areas spreading chikungunya virus and 4 dengue serotypes but Aedes albopictus was more confined to the urban areas (Ioos et al, 2014; Petersen et al., 2015). The migration of humans to different places in the urban areas makes way for the rapid transmission of vectors along with the diseased humans.

Aedes albopictus has successfully colonized nearly every Mediterranean country and is constantly being dispersed throughout Central and Northern Europe. Aedes japanicus in Central Europe, Aedes atropalpus in North Italy and Netherlands, Aedes koreicus at the Swiss-Italian border, Belgium (Marcondes \& Ximenes, 2015) and Germany and Aedes aegypti on Madeira, Russia, Abkhazia and Georgia (Boukraa et al., 2015) have established themselves as ZIKV vectors.

Vectors such as Aedes aegypti and Aedes dalizeli feed on various animal species and humans and increase the chances of variability of the genetic material of ZIKV strains (Duffy et al., 2009; Kuno \& Chang, 2005).

The increase in the human population, the migratory movements and the limitless growth of slums have provided the potential to increase the frequency of 
Aedes aegypti and Aedes albopictus as they have the capability to live in stagnant water collections found in the human gatherings (Marcondes \& Ximenes, 2015; Erguler et al., 2016; Calvez et al., 2016; Ioos et al., 2014).

On $15^{\text {th }}$ May, 2017, the Ministry of Health and Family Welfare Government of India reported three cases of Zika Virus disease that were confirmed in the laboratory in Bapunagar area, Ahmedabad district, Gujarat State, India. Zika Virus disease was detected and confirmed through RT-PCR test by routine laboratory surveillance at B. J. Medical College, Ahmedabad, Gujarat. WHO (2017)

From the table, it can be seen that, 15 species of Aedes, 3 species of Anopheles, 2 species of Culex and one species of Mansonia may be responsible for spreading the ZIKV through both the Asian and African lineages. The finding of antibodies against virus in these mosquitoes doesn't make them competent vectors, but do potentiate them as probable vectors. Amongall the 15 species of Aedes mosquito only two species, Aedes aegypti and Aedes africanus are the predominant ones. They are the principal vectors of most of the major mosquito borne viral diseases across the world. They have high ecological adaptability and genetic flexibility that enables them to survive in the different environments of rural, semi urban and urban areas.

\section{Principal and Possible Reservoirs of Zikv}

ZIKV was first isolated from rhesus monkey in a 1947 study in Zika Forest, Uganda but the virus reservoir was not yet identified (Dick et al.,1952). Mild or no clinical presentations were displayed by the monkeys but after 5 days of experimental infection, neutralizing antibodies were developed in them (Dick,1952). Yet again, wild mammals in Senegal showed the presence of anti-ZIKV antibodies during 1967-1968 (Bres,1970). In 1978, antiZIKV antibodies were reported in ducks, goats, cows, horses, bats and water buffaloes in Lombok, Indonesia but were not detected in rats, chickens or wild birds. This highlighted the circulation of the virus in domestic animals (Olson et al., 1983).

Antibodies against ZIKV were next detected in monkeys in Gabon in 1982. (Saluzzo et al.,1982) In Pakistan, antibodies against ZIKV were detected in the year 1983 among goats, domestic sheep, rodents and in human sera as well (Darwish et al.,1983). In 1996-1997, in Borneo Malaysia, samples collected from wild and semi-captive orangutans showed the presence of antibodies against ZIKV (Wolfe et al., 2001). From 1968 to 2002, the samples that were collected from West African monkeys showed the presence of ZIKV that was detected with the help of RT-PCR (Faye et al., 2014). From 1962-2008, the samples collected from the West African monkeys showed the presence of specific ZIKV antigens with serology assays (Table 2.) (Althouse et al., 2015). The antibody detection assays can have the risk of cross-reaction with other co-circulating viruses in a particular organism (Vorou, 2016), so detection of antibody doesn't confirm an animal as a reservoir, but mark them as potential reservoir.

Table 2: Animals in which ZIKV or antibody for the same was isolated or detected

\begin{tabular}{|c|c|c|c|}
\hline $\begin{array}{c}\text { Year of } \\
\text { collection }\end{array}$ & Animal & Location & Reference \\
\hline 1947 & Rhesus monkey & Zika Forest, Uganda & $\begin{array}{c}\text { Dick } \text { et al.,1952; Mlakar } \\
\text { et al., 2016 }\end{array}$ \\
\hline $1967-1968$ & Wild mammals, monkeys & Senegal & P.Bres.,1970 \\
\hline 1962 and 1964 & Wild mammals, monkeys & Ethiopia & P.Bres.,1970 \\
\hline 1969 & $\begin{array}{c}\text { Monkeys of Bwamba } \\
\text { country }\end{array}$ & $\begin{array}{c}\text { Bwamba country, Kisubi, } \\
\text { Uganda, Zika forest }\end{array}$ & G.W.Dick.,1952 \\
\hline
\end{tabular}




\begin{tabular}{|c|c|c|c|}
\hline 1978 & $\begin{array}{c}\text { Ducks, goats, cows, horses, } \\
\text { bats, rats, water buffaloes }\end{array}$ & Lombok, Indonesia & Faye et al.,2014 \\
\hline 1982 & Monkeys & Gabon & Saluzzo et al.,1982 \\
\hline 1983 & $\begin{array}{c}\text { Rodents, domestic sheep } \\
\text { and goats }\end{array}$ & Pakistan & Darwish et al.,1983 \\
\hline $1996-1997$ & $\begin{array}{c}\text { Wild and semi-captive } \\
\text { orang-utans }\end{array}$ & Malaysia, Borneo & Wolfe et al., 2001 \\
\hline $1968-2002$ & Monkeys & $\begin{array}{c}\text { West Africa, Senegal, } \\
\text { Central Africa Republic }\end{array}$ & Faye et al.,2014 \\
\hline $1962-2008$ & Monkey & Senegal & Althouse et al.,2015 \\
\hline
\end{tabular}

\section{Eco-climatic Factors and Territorial Expansion of Aedes Vectors}

Research showed that Asian tiger mosquito (Aedes albopictus) is expanding its territory along with climate change in North-eastern US (Rochlin et al., 2013). Numerous independent studies have revealed that eggs of Aedes albopictus in diapause state are unable to survive extreme cold temperatures in the winter. Various parameters were selected for drawing the correlation between availability of Aedes albopictus and climate of the concerned place. Several factors which include the annual mean temperature, mean diurnal range, isothermality, temperature seasonality, maximum temperature of warmest month, minimum temperature of coldest month, temperature annual range, mean temperature of wettest quarter, mean temperature of driest quarter, mean temperature of warmest quarter, mean temperature of coldest quarter, annual precipitation, precipitation of wettest month, precipitation of driest month, precipitation seasonality, precipitation of wettest quarter, precipitation of driest quarter, precipitation of warmest quarter, precipitation of coldest quarter, January precipitation, land use/cover, elevation, were used as the main model systems. Among all these, 'mean temperature of the coldest quarter' is proved to be the most important model system. Due to global warming the mean temperature of all the continents is shifting towards the higher temperature. Hence the previously known lowest temperature is not valid anymore. Moreover, studies based on the tolerance of Aedes mosquitoes to cold temperature in lab condition for 24 hours have shown to be not very fruitful. Ultimately the mean temperature of coldest quarter matters the most in the context of territory expansion of Aedes.

\section{DISCUSSION}

ZIKV has been isolated from various species of mosquitoes belonging to different genera in Africa and other areas of the world (Table 1). Although, a couple of species belonging to the genera Aedes, i.e. Aedes aegypti and Aedes albopictus seem to play a significant role in human outbreaks of ZIKV. The finding of the virus/pathogen in a particular species of mosquito is not a proof by itself that the species is a vector to man/animal. Additional evidences such as that the species is common enough and has reasonable contact with humans or both animals and humans (in case of zoonotic diseases), may therefore be helpful. Nevertheless, isolation of ZIKV from other mosquito species has added a new dimension in the epidemiology of the disease and some of them might have some role as a complementary vector. The diverse feeding habits of the principal and complementary vectors possibly keep the virus circulating in the reservoirs throughout the year. ZIKV-infected $C x$. quinquefasciatus from urban areas with high microcephaly incidence in Recife, Brazil has been reported by Guedes et al., (2017). Interestingly, they were able to detect the presence of ZIKV in the midgut, salivary glands and saliva of artificially fed $C x$. quinquefasciatus. These findings indicate that there might be a wider range of ZIKV vectors than anticipated. Amraoui et al., 2016, however stated that 
this species were experimentally unable to transmit ZIKV. Nevertheless, the attainment of the vectorial status itself is a dynamic phenomenon and with the passage of time some suspected mosquitoes may become epidemiologically important which donot have any substantial public health significance at present. Global warming, urbanization, globalization of humans are likely to reshape the ecology of many vector mosquitoes such as ubiquitous $C x$. quinquefasciatus, which might have a wide-ranging effect on the epidemiology of the mosquito-borne diseases including ZIKV (Bhattacharya \& Basu, 2016). Animal hosts such as monkeys are recognized as animal reservoirs and play an important role in the amplification and maintenance of the ZIKV. Apart from recognized potential reservoir/ amplifying hosts, ZIKV/antibody has also been detected in several other homoeothermic vertebrates (Table 2). The finding of the antibody however, is not itself a proof that the animal is a reservoir host of the virus. As time passes by, the animal and arbovirus interactions may change dynamically and some of these animals from which Zika antibodies have been detected could transform in epidemiologically important ways and subsequently may attain the status of a potential reservoir/amplifying hosts of the ZIKV in future, especially in the context of changing climate and environment. The animal sources and viral lineages suggest that ZIKV is dispersed widely among distinct animal species without a clear pattern of preferences, which might be associated to the maintenance of the enzootic cycle of ZIKV with a broad range of hosts and vectors (Kuno \& Chang, 2005). Along with the recognized principal reservoir hosts i.e., rhesus monkeys, some of these animals might have some complementary and secondary role in the maintenance of the enzootic cycle of the ZIKV. The principal and complementary reservoir hosts possibly keep the virus circulating perennially in nature and epizootic occurs at the time of higher than average level of virus circulation. The virus spills over to the humans during this higher level of virus circulation in nature i.e., during the epizootic cycle of the virus (O'brien et al., 2011). A similar phenomenon has been evident in case of Japanese encephelities (JE) virus, a zoonotic mosquito borne disease (Bhattacharya et al., 1986). Transovarial transmission of ZIKV in mosquitoes (Ciota et al., 2017) and via semen between sexual partners in humans during intercourse (Petersen et al., 2016) has also been reported. This is possibly an important mechanism for the maintenance of ZIKV in nature especially in the urban areas.The factors like global warming, travel associated dissemination; also possibly contribute to the viral sustenance in urban areas. There is substantial evidence that temperature variability is a major driving force of disease transmission across diverse vector-borne pathogen systems (Mordecai et al., 2017; Liu et al., 2014; Siraj et al., 2014). Mosquitoes are ectothermic animals and their physiology, life history and vectorial capacity (Murdock et al., 2013; Adelman et al., 2013; Liu et al., 2014; Mordecai et al., 2017; Delatte et al., 2009; Mordecai et al., 2014; Kilpatrick et al., 2008) exhibit unimodal responses to changes in temperature. Mosquito species which have a preference towards animal blood could get the virus from a wide range of low viraemic animals, but may not be able to attain the infective stage and transmission competence as there is inadequate titre level and short duration of viraemia in those animals. Along with sexual transmission, transovarial transmission of ZIKV from mother to foetus is causing the most destructive outcomes such as microcephaly in new-born babies (Abidi et al., 2016; Tesh et al., 2011). These observations point out the alarming fact that ZIKV has potential disposition for germ line mediated transfer, a trait previously not perceived among other mosquito-borne viruses. Although the ZIKV infections have been found in diverse non-human vertebrates in natural and laboratory condition, additional evidences like titre level duration, vector predilection, host susceptibility and immune response of the newborn host population are needed to recognize those animals to be the potential reservoirs/amplifying hosts of the virus (Table 2). In natural condition, low viraemia could cause the transmission and infection to mosquitoes; however, this depends on low viraemic host numbers and doseinfection transmission relationship, duration of viraemia and the number of the vector mosquitoes biting these low viraemic hosts. Animal and arbovirus interaction is a dynamic phenomenon and along with sexual transfer, it poses a potential future threat of possible genetic alterations and modification. This may lead to germline compromisation of massive consequences in the unsuspecting hosts. Extensive surveillance of ZIKV in competent mosquito vectors and seroepidemiological 
study would be helpful in understanding the vectorand vertebrate/host diversity as well as for assessing the risk of ZIKV infection in Zika endemic and non-endemic areas.

\section{CONCLUSION}

Recent outbreaks of ZIKV, a mosquito borne zoonotic Flavivirusled World Health Organization (WHO) to declare a Public Health Emergency (PHE) of International concern. As there is no political boundary to which viruses and mosquito vectors restrict their activities especially in this globalised world, the possibility of the entry of ZIKV in hitherto unaffected regions by aircrafts and ships having infected mosquito vectors, animal reservoirs and humans is a matter of concern. Hence, a sustained vector-virus and vertebratehost surveillance is an imperative necessity in Zika endemic and non-endemic regions in order to formulate area-wise strategies for the prevention offuture outbreak, if any.

\section{ACKNOWLEDGEMENTS}

The authors are grateful to Dr. Lyle R. Petersen, MD, $\mathrm{MPH}$, Director of the Division of Vector-Borne Diseases, National Center for Emerging and Zoonotic Infectious Diseases, Centers for Disease Control and Prevention, Fort Collins, USA for his kind suggestions and valuable comments during the preparation of the manuscript and Professor A. K. Hati, former Director Calcutta School of Tropical Medicine, Kolkata, India for his kind advise and encouragement. Thanks are due to Ms. Chandrima Bose, Post Graduate Department of Zoology, Asutosh College, Kolkata, India for her assistance.

\section{REFERENCES}

Adelman, Z.N., Anderson, M.A., Wiley, M.R., Murreddu, M.G., Samuel, G.H., Morazzani, E.M. \& Myles, K.M. (2013). Cooler temperatures destabilize RNA interference and increase susceptibility of disease vector mosquitoes to viral infection. PLoS Neglected Tropical Diseases, 7(5).

Alera, M.T., Hermann, L., Tac-An, I.A., Klungthong, C., Rutvisuttinunt, W., Manasatienkij, W., Villa, D., Tha is omboonsuk, B., Velasco,J.M., Chinnawirotpisan, P. \& Lago, C.B. (2015). Zika virus infection, Philippines. Emerging infectious diseases, 21(4), pp 722-724.

Althouse, B.M., Hanley, K.A., Diallo, M., Sall, A.A., Ba, Y., Faye, O., Diallo D, Watts D.M., Weaver S.C. \& Cummings D.A. (2015). Impact of climate and mosquito vector abundance on sylvatic arbovirus circulation dyhnamics in Senegal. The American Journal of Tropical Medicine, 92(1), pp 88-97.

Berthet, N., Nakouné, E., Kamgang, B., Selekon, B., Descorps-Declère, S., Gessain, A., Manuguerra, J.C. \& Kazanji, M. (2014). Molecular characterization of three Zikaflaviviruses obtained from sylvatic mosquitoes in the Central African Republic. Vector-Borne and Zoonotic Diseases, 14(12), pp 862-865.

Bhattacharya S., Chakraborty, S.K., Chakraborty S., Ghosh, K.K., Palit, A., Mukherjee, K.K., Chakraborty, M.S., Tandon, N. \& Hati, A.K. (1986). Density of Culexvishnui and appearance JE antibody in sentinel chicks and wild birds in relation to JE cases, Tropical and Geographical Medicine, 38(1), pp 46-50.

Bhattacharya, S. \& Basu, P. (2014). Japanese Encephalitis Virus (JEV) infection in different vertebrates and its epidemiological significance: a Review. International Journal of Fauna and Biological Studies, 1(6), pp 32-37.

Bhattacharya, S. \& Basu, P. (2016). A new dimension in the dengue epidemiology with special reference to the genetic diversity of the virus: A review. International Journal of Fauna and Biological Studies, 3(3), pp 29-41.

Bhattacharya, S. \& Basu, P. (2016). The Southern House Mosquito, Culex quinquefasciatus: profile of a smart vector. Journal of Entomology and Zoology Studies, 4(2), pp 73-81.

Bhattacharya, S. (2009). Mosquito borne diseases in India with special reference to malaria vectors and their control. Journal of the Asiatic Society, 39(4) pp 97-140.

Boukraa, S., Dekoninck, W., Versteirt, V., Schaffner, F., Coosemans, M., Haubruge, E. \& Francis, F. (2015). 
Updated checklist of the mosquitoes (Diptera: Culicidae) of Belgium. Journal of Vector Ecology, 40(2), pp 398-407.

Bres, P. (1970). Recent data from serological surveys on the prevalence of arbovirus infections in Africa, with special reference to yellow fever. Bulletin of the World Health Organization, 43(2), pp 223-267.

Calvez, E., Guillaumot, L., Millet, L., Marie, J., Bossin, H., Rama, V. Faamoe, A., Kilama, S., Teurlai, M., Mathieu-Daudé, F. \& Dupont-Rouzeyrol, M. (2016). Genetic diversity and phylogeny of Aedes aegypti, the main arbovirus vector in the Pacific. PLOS Neglected Tropical Diseases,10(1): e0004374

Chippaux, A., Chippaux-Hyppolyte, C., MontenyVandervorst, N. \& Souloumiac-Deprez D. (1981). Diagnostic de plusieurscas de fièvre jaune en zone d'émergenceendémiqueen Côte-d'Ivoire. Medecine Tropicale, 41(1), pp 53-61.

Ciota, A.T., Bialosuknia, S.M., Ehrbar, D.J. \& Kramer, L.D. (2017). Vertical Transmission of Zika Virus by Aedes aegypti and Ae. albopictus Mosquitoes. Emerging Infectious Disease, 23(5), pp 880-882.

Darwish M.A., Hoogstral H., Roberts T.J., Ahmed I.P. \& Omar F. (1983). A serological surcvey for certain arboviruses (Togaviridae) in Pakistan. Transactions of the Royal Society of Tropical Medicine and Hygiene, 77(4), pp 442-445.

Delatte, H., Gimonneau, G., Triboire, A. \& Fontenille, D. (2009). Influence of temperature on immature development, survival, longevity, fecundity, and gonotrophic cycles of Aedes albopictus, vector of chikungunya and dengue in the Indian Ocean. Journal of Medical Entomology, 46(1), pp 33-41.

Diallo, D., Sall A.A., Diagne, C.T., Faye, O., Ba, Y., Ba Y., Hanley K.A., Buenemann M., Weaver S.C. \& Diallo M., (2014). Zika virus emergence in mosquitoes in southeastern Senegal. PLoS One, $9(10)$.

Diallo, M., Thonnon, J., Traore-Lamizana, M. \& Fontenille, D. (1999). Vectors of Chikungunya virus in Senegal: current data and transmission cycles. The American Journal of Tropical Medicine and Hygiene, 60(2), pp 281-286.

Dick, G.W., Kitchen, S.F. \& Haddow, A.J.(1952). Zika virus. I. Isolations and serological specificity. Transactions of the Royal Society of Tropical Medicine and Hygiene, 46(5), pp 509-520.

Dick, G.W. (1952). Zika virus. II. Pathogenicity and physical properties. Transactions of the Royal Society of Tropical Medicine and Hygiene, 46(5), pp 521-534.

Duffy, M.R., Chen, T.H., Hancock, W.T., Powers, A.M., Kool, J.L., Lanciotti, R.S., Pretrick M., Marfel M., Holzbauer S., Dubray C., Guillaumot L., Griggs A., Bel M., Lambert A.J., Laven J., Kosoy O., Panella A., Biggerstaff, B.J., Fischer M. \& Hayes E.B. (2009). Zika virus outbreak on Yap Island, Federated States of Micronesia. New England Journal of Medicine, 360, pp 2536-2543.

Erguler, K., Smith-Unna, S.E., Waldock, J., Proestos, Y., Christophides, G.K., Lelieveld, J. \& Parham, P.E. (2016). Large-Scale Modelling of the Environmentally-Driven Population Dynamics of Temperate Aedes albopictus (Skuse). PLoS One,11(2): e0149282.

Faye, O., Freire, C.M.C., Iamarino, A., Faye, O., Oliveira, V.C. de. J., Diallo, M., Zanotto, P.M.A. \& Sall, A.A. (2014). Molecular Evolution of Zika Virus during Its Emergence in the $20^{\text {th }}$ Century. PLOS Neglected Tropical Disease, 8(1).

Fagbami, A. (1978). Human arthropod-borne virus infections in Nigeria: serological and virological investigations at Shaki, Oyo State. Journal of hygiene, epidemiology, microbiology, and immunology, 22(2), pp 184-189.

Gong, Z., Gao, Y. \& Han, G.Z. (2016). Zika Virus: Two or Three Lineages? Trends in Microbiology, 24(7), pp 521-522.

Georges, A.J., Saluzzo, J.F. \& Gonzalez J.P. (1980). ArbovirosesenCentrafrique: incidence et aspects diagnostiques chez l'homme. Tropical Journal of Medical Research, 40, pp 561-568.

Grard, G., Caron, M., Mombo, I.M., Nkoghe, D., 
Mboui Ondo, S., Jiolle D., Fontenille, D., Paupy, C. \& Leroy, E.C., (2014). Zika virus in Gabon (Central Africa) 2007: a new threat from Aedes albopictus? PLOS Neglected Tropical Disease. $8(2): \mathrm{e} 2681$.

Haddow, A.J., Williams, M.C., Woodall, J.P., Simpson, D.I.H. \& Goma, L.K.H. (1964). Twelve isolations of Zika virus from Aedes (Stegomyia) africanus (Theobald) taken in and above a Uganda forest. Bulletin of the World Health Organization, 31(1), pp 57.

Haddow, A.D., Schuh, A.J., Yasuda, C.Y., Kasper, M.R., Heang, V., Huy R., Guzman, H. Tesh, R.B. \& Weaver S.C. (2012). Genetic characterization of Zika virus strains: geographic expansion of the Asian lineage. PLOS Neglected Tropical Diseases, 6(2): e1477

Heang, V., Yasuda, C.Y., Sovann, L., Haddow, A.D., Travassos da Rosa, A.P., Tesh, R.B. \& Kasper, M.R. (2012). Zika virus infection, Cambodia, 2010. Emerging Infecious Diseases, 18(2), pp 349-51.

Imperato, P.J. (2016). The Convergence of a Virus, Mosquitoes, and Human Travel in Globalizing the Zika Epidemic, Journal of Community Health, 41(3), pp 674-9.

Ioos, S., Mallet, H.P., Leparc Goffart, I., Gauthier, V., Cardoso, T. \& Herida, M. (2014). Current Zika virus epidemiology and recent epidemics. Medecineet Maladies Infectieuses Journal, 44(7), pp 302-307.

Kampango, A. \& Abilio, A.P.(2016). The Asian tiger hunts in Maputo city---the first confirmed report of Aedes (Stegomyia) albopictus in Mozambique. Parasite Vectors, 9, pp 76.

Kilpatrick, A.M., Meola, M.A., Moudy, R.M. \& Kramer, L.D. (2008). Temperature, viral genetics, and the transmission of West Nile virus by Culex pipiens mosquitoes. PLOS Neglected Tropical Diseases, 4(6).

Kuno, G. \& Chang, G.J. (2005). Biological transmission of arboviruses: re-examination of and new insights into components, mechanisms and unique traits as well as their evolutionary trends.
Clinical MicrobiologyReviews, 18(4), pp 608-637.

Kuno, G. \& Chang, G.J.J. (2007). Full length sequencing and genomic characterization of Bagaza, Kedougou, and ZiVes. Archives of Virology, 152(4), pp 687-96.

Lanciotti, R.S., Kosay, O.L., Laven, J.L., Velez, J.O., Lambert, A.J., Johnson A.J., Stanfield S.M. \& Duffy. M.R. (2008). Genetic and serologic properties of Zika Virus associated with an epidemic, Yap state, Micronesia, 2007. Emerging Infectious Diseases, 14(8), pp 1232-1239.

Ledermann, J.P., Guillaumot, L., Yug, L., Saweyog, S.C., Tided, M., Machieng, P., Pretrick, M., Marfel, M., Griggs, A., Bel, M. \& Duffy, M.R. (2014). Aedes hensilli as a potential vector of Chikungunya and Zika viruses. PLOS Neglected Tropical Diseases, 8(10).

Le Gonidec, G. \& Dhiver, F. (1973). Le virus de la fièvre jaune et autres arbovirus dans le Sénégal oriental: étude des serums humains. Bulletin de la Société de Pathologie Exotique, 66, pp 603-15.

Liu-Helmersson, J., Stenlund, H., Wilder-Smith, A. \& Rocklov, J. (2014). Vectorial capacity of Aedes aegypti: effects of temperature and implications for global dengue epidemic potential. POLS One, 9(3): e89783.

Liu, Z.Y., Shi, W.F. \& Qin, C.F. (2019). The evolution of Zika virus from Asia to the Americas. Nature Reviews Microbiology, 17(3), pp 131-139.

Marchette, N.J., Garcia, R. \& Rudnick, A. (1969). Isolation of Zika virus from Aedes aegypti mosquitoes in Malaysia. American Journal of Tropical Medicine and Hygiene, 18(3), pp 411-415.

Marcondes, C.B. \& Ximenes, M.F. (2015). Zika virus in Brazil and the danger of infestation by Aedes (Stegomyia) mosquitoes. Revistada Sociedade Brasileirade Medicina Tropical, 49(1), pp 4-10.

Mlakar, J., Korva, M., Tul, N., Popovic, M., PolisakPrijateli, M., Mraz, J., Kolenc, M., Resman Rus, K., Vesnaver Vipotnik, T., Fabjan Vodušek, V., Vizjak A., Pižem, J., Petrovec, M. \& Avšič Županc, T (2016). Zika virus associated with microbiology. 
The New England Journal of Medicine, 374(10), pp 951-958.

Mordecai, E.A., Paaijmans K.P., Johnson L.R., Balzer C., Ben-Horin T., de Moor E., McNally A., Pawar S., Ryan S.J., Smith T.C. \& Lafferty K.D. (2013). Optimal temperature for malaria transmission is dramatically lower than previously predicted. Ecology Letters, 16, pp 22-30.

Mordecai, E, Cohen, J.M., Evans, M.V., Gudapati, P., Johnson, L.R., Lippi, C.A., Miazgowicz, K., Murdock, C.C., Rohr, J.R., Ryan, S.J., Savage, V., Shocket, M.S., Stewart Ibarra, A., Thomas, M.B. \& Weikel, D.P., (2017). Detecting the impact of temperature on transmission of Zika, dengue, and chikungunya using mechanistic models. PLOS Neglected Tropical Diseases, 11(4).

Murdock, C.C., Paaijmans, K.P., Bell, A.S., King, J.G., Hillyer, J.F., Read, A.F. \& Thomas, M.B. (2012). Complex effects of temperature on mosquito immune function. Proceedings of the Royal Society B: Biological Sciences, 279(1741), pp 3357-3366.

Mourya, D.T., Shil, P., Sapkal, G N. \& Yadav, P.D. (2016). Zika virus: Indian perspectives. Indian Journal of Medical Research, 143(5), pp 553-564.

Ngoagouni, C., Kamgang, B., Nakoune, E., Paupy, C. \& Kazanji, M., (2015). Invasion of Aedesalbopictus (Diptera: Culicidae) into Central Africa: what consequences for emerging diseases? Parasite Vectors, 8(191).

Olson, J.G., Ksiazek, T.G., Gubler, D.J., Lubis, S.I., Simanjuntak, G., Lee, V.H., Nalim S. \& Juslis K., See R. (1983). A survey for arboviral antibodies in sera of humans and animals in Lombok, Republic of Indonesia. Annals of Tropical Medicine and Parasitology, 77(2), pp 131-137.

Olson, J.G. \& Ksiazek, T.G. (1981). Zika virus, a cause of fever in Central Java, Indonesia. Transactions of the Royal Society of Tropical Medicine and Hygiene, 75(3), pp 389-393.

Paixao, E.S., Teixeira, M.G. \& Rodrigues, L.C. (2018). Zika, Chikungunya and dengue: teh causes and threats of new and reemergingarboviral diseases,
BMJ Glob Health, 3(1).

Petersen, E., Wilson, M.E., Touch, S., McCloskey, B., Mwaba, P., Bates, M., Dar, O., Mattes, F., Kidd, M., Ippolito, G., Azhar, E.I. \& Zumla, A. (2016). Rapid spread of Zika virus in the Americas-Implications for public health preparedness for mass gatherings at the 2016 Brazil Olympic Games. International Journal of Infectious Diseases, 44, pp11-15.

Petersen, E.E., Meaney-Delman, D., Neblett-Fanfair, R., Havers, F., Oduyebo, T., Hills, SL., Rabe I.B., Lambert, A., Abercrombie, J., Martin, S.W., Gould, C.V., Oussayef, N., Polen, K.N., Kuehnert, M.J., Pillai, S.K., Petersen, L.R., Honein, M.A., Jamieson, D.J. \& Brooks, J.T. (2016). Update: Interim Guidance for Preconception Counseling and Prevention of Sexual Transmission of Zika Virus for Persons with Possible Zika Virus Exposure - United States, September 2016. Morbidity and Mortality Weekly Report, 65(39), pp 1077-1081.

Porse, C.C., Messenger, S., Vugia, D.J., Jilek, W., Salas, M., Watt, J. \& Kramer, V. (2018). TravelAssociated Zika Cases and Threat of Local Transmission during Global Outbreak, California, USA. Emerging Infectious Diseases, 24(9), pp 1626-1632.

Robin, Y. \& Mouchet, J. (1975) Enquêtesérologique et entomologique sur la fièvre jaune en Sierra Leone. Bulletin de la Société de pathologie exotique, 68, pp 249-58.

Rochlin, I., Ninivaggi, D.V., Hutchinson, M.L. \& Farajollahi, A., (2013). Climate change and range expansion of the Asian tiger mosquito (Aedes albopictus) in North eastern USA: implications for public health practitioners. PloS one, 8(4).

Roth, A., Mercier, A., Lepers, C., Hoy, D., Duituturaga, S., Benyon, E., Guillaumot, L. \& Souares, Y. (2014). Concurrent outbreaks of dengue, chikungunya and Zika virus infections-an unprecedented epidemic wave of mosquito-borne viruses in the Pacific. Eurosurveillance, 19(41).

Saluzzo, J.F., Iyanoff, B., Languillat, G. \& Georges A.J. (1982). Serological survey for arbovirus antibodies 
in the human and simian populations of the SouthEast of Gabon (author's transI). Bulletin de la Sociétéde pathologie exotique, 75(3), 262-266.

Shen, S., Shi, J., Wang, J., Tang, S., Wang, H., Hu, Z. \& Deng, F. (2016). Phylogenetic analysis revealed the central roles of two African countries in the evolution and worldwide spread of Zika virus, Virologica Sinica, 31(2), pp 118-130.

Simonin, Y., van Riel, D., Van de Perre, P., Rockx, B. \& Salinas, S. (2017) Differential virulence between Asian and African lineages of Zika virus. PLOS Neglected Tropical Diseases, 11(9).

Simon-Loriere, E. \& Holmes, E.C. (2011) Why do RNA viruses recombine? Nature Reviews Microbiology, 9(8), pp 617-626.

Siraj, AS., Santos-Vega, M., Bouma, MJ., Yadeta, D., Carrascal, D.R. \& Pascual, M. (2014). Altitudinal changes in malaria incidence in highlands of Ethiopia and Colombia. Science, 343(6175), pp 1154-1158.

Sirohi, D., Chez, Z., Sun, L., Klose, T., Pierson, T.C., Rossmann, M.G. \& Kuhn, R.J. (2016). The $3.8 \AA$ resolution cryo-EM structure of Zika virus. Science, 352 (6284), pp 467-70.

Taucher, C., Berger, A. \& Mandl, C.W. (2010). A transComplementing Recombination Trap Demonstrates a Low Propensity of Flaviviruses for Intermolecular Recombination. Journal of Virology, 84(1), pp 599-611.

Tesh, B.D., Foy, D. B., Kobylinski, C.K., Foy, L., Chilson, J., Blitvich, J.B., Travassos da Rosa, A.,
Haddow, D.A. \& Lanciotti, S.R. (2011). Probable Non-Vector borne Transmission of Zika Virus, Colorado, USA. Emerging Infectious Diseases, 17(5), pp 880-882.

Vorou, R. (2016). Zika virus, vectors, reservoirs, amplifying hosts, and their potential to spread worldwide: what we know and what we should investigate urgently. International Journal of Infectious Diseases, 48, pp 85-90.

Wang, L., Valderramos, S.G., Wu, A., Ouyang, S., Li, C. \& Brasil, P. (2016). From mosquitos to humans: genetic evolution of Zika virus. Cell Host \& Microbe, 19(5), pp 561-5.

Weinbren, M.P. \& Williams, M.C. (1958). Zika virus: further isolations in the Zika area, and some studies on the strains isolated. Transactions of the Royal Society of Tropical Medicine and Hygiene, 52, pp 263-268.

WHO (2017), Retrieve from: www.who.int/csr/don/ 26-may-2017-zika-ind/en/cited on 24.5.2017.

Wolfe, N.D., Kilbourn, A.M., Karesh, W.B., Rahman, H.A., Bosi, E.J., Cropp, B.C., Andau M., Spielman A. \& Gubler D.J. (2001). Sylvatic transmission of arboviruses among Borneanorang-utans. The American Journal of Tropical Medicine and Hygiene, 64(5-6), pp 310-316.

Wong, P.S., Li, M.Z., Chong, C.S., Ng, L.C. \& Tan, C.H., (2013). Aedes (Stegomyia) albopictus (Skuse): a potential vector of Zika virus in Singapore. PLOS Neglected Tropical Diseases, 7(8). e2348. 